\title{
Leadership role of the Human Resources department in crisis situations: the case of COVID-19 pandemic
}

\author{
Jelena Lukić Nikolić
}

High School of Modern Business, Belgrade, Serbia

https://orcid.org/0000-0003-0632-8974

Snežana Lazarević

College of sports and health, Belgrade, Serbia

https://orcid.org/0000-0003-2048-1684

Jamila Jaganjac

University "VITEZ“, Travnik, Bosnia and Herzegovina

https://orcid.org/0000-0001-9587-3098

\begin{abstract}
The paper points out the leading role of the HR department in crisis situations, with special emphasis on the crisis caused by the COVID-19 pandemic, which affected the whole world in early 2020 . Regardless of the intensity and form in which they occur, crises threaten the functioning and survival of organizations.

The HR department is an important factor in the successful functioning of organizations and, in a period of crisis, this department takes a leading role in the process of crisis management and subsequent recovery. During COVID-19 pandemic, the HR department of every organization had to confront new challenges in order to protect the health of employees, while ensuring the normal functioning of organizations.

In order to find out how this department dealt with crisis that occurred, empirical research with a specially designed questionnaire was conducted and filled in by 108 respondents from Serbia, Bosnia and Herzegovina, and Croatia in 2020.

The research results showed that HR department has taken a leading role in preserving the health and safety of employees, as well as in the process of adapting organizations to function in crisis conditions. According to results, the key activities carried out by the HR department in organizations are work from home (wherever the nature of the work allowed), flexible working hours, reorganization of the working space to achieve the required physical distance between employees, improved hygiene measures, etc. In addition, the research results showed that, during the global COVID-19 pandemic, the HR departments took an active role in providing psychological assistance to employees to adapt to new conditions and ways of working.
\end{abstract}

\section{Keywords:}

leadership, HR department, employees, crisis situation, organizational behaviour

\section{Introduction}

There is not a single organization that has not been exposed to a crisis situation during its functioning and operating. Unforeseen crisis events such as natural disasters, health and environmental disasters, technological crises, economic and market crises, political instabilities, terrorist attacks, business crises, corporate scandals, defective products, etc., have farreaching consequences for an organization and employees and require rapid response (Mitroff, 1988; Hart, Rosenthal, \& Kouzmin, 1993; Reilly, 2008; Wang, 2008). Whether an organization will survive in the conditions imposed on it by a crisis situation depends on the speed and the way in which it will react and organize its operation (Lukić, Jaganjac, \& Lazarević, 2020). Therefore, 
knowledge and experience gained by resolving crisis situations are the basis for crisis management and its future success in preventing and minimizing crisis effects, but also in taking advantage of new opportunities.

Due to their talents, knowledge, skills, behaviour, and work results, employees are the driving force of every organization (Lukić \& Lazarević, 2019). One important condition that needs to be met is that employees are engaged hard working, positive, optimistic, full of energy, creative, productive, effective, efficient, ready to help others, ready to stay overtime when needed, ready to learn and adapt to new circumstances (Lukić Nikolić, 2021). Everything that takes place in organizations - production and sale of products, provision of services, innovation, problem solving, decision making, improvement of business processes, happens thanks to employees (Federman, 2009). Human capital is a dynamic category that influences long-term success more than any other factor, depending on how companies invest in it (Jaganjac \& Obhođaš, 2019). Human resource management implies a holistic and planned approach to managing human resources and it has become one of the most important factors for the survival, growth, and development of an organization in recent years (Mwaniki \& Gathenya, 2015). It includes all activities and processes related to employees and their experience - employee planning, job analysis, job design, recruitment and selection process, onboarding, socialization, training and development, performance measurement, reward and motivation system, employee career development, interpersonal relationships, conflict resolution, communication, team building and teamwork, diversity and inclusion, employee satisfaction, commitment, loyalty, morale and engagement, and employee resignation process. During the implementation of human resource management activities and processes, the organizational unit dealing with HR issues must cooperate with top management and other organizational units to ensure a unique, holistic approach to the organization (Sparrow, Hird, \& Cooper, 2015).

One of the crisis situations that the whole world faced at the beginning of 2020 is the appearance of the virus SARS-CoV-2, known as COVID-19. The rapid transmission of the virus and its consequences on human health led to the pandemic declaration in March 2020 (European Centre for Disease Prevention and Control, 2020).
Health of people became priority, putting life and safety at the centre of every activity and decision (Figus, 2021).

The sudden onset and far-reaching social, psychological, and economic consequences of the COVID-19 pandemic have led to a number of challenges and difficulties in the functioning of organizations (Yang, Peng, Wang, Guan, Jiang, $\mathrm{Xu}$, Sun \& Ghang, 2020). They suddenly had to navigate in unknown and unexpected circumstances with the aim to find new solutions on how to keep their operations and business in existence (Carnevale \& Hatak, 2020). Human Resources (HR) departments had to confront new challenges in order to protect and preserve the health of employees, while ensuring the normal functioning of an organization (Meister, 2020; Tansey, 2020). On the other hand, employees are becoming more responsible for their behaviour during this crisis that impacts their health and safety. They must be aware of the importance of physical distance and new, improved hygiene habits.

\section{The role and significance of the HR Department in a crisis situation}

The HR department is an important factor in the successful functioning of organizations and, in a crisis period, this department takes a leading role in the process of crisis management and recovery that follows it (Barton, 2000; Wooten \& James, 2008; Human Resources Management Association, 2014; Mirzapour, Toutian, Mehrara, \& Khorrampour, 2019). Human resource management has a leading role in sustaining the organizational performance in times of crisis (Gunnigle, Lavelle, \& Monaghan, 2019). The key activities of the HR department in crisis situations are maintaining the health and safety of employees, training and coaching employees on how to function in changed conditions and how to cope with a crisis situation, and sometimes these are less desirable activities - reducing costs, salaries, benefits, and finally the number of employees (Burma, 2014). The HR department should train and prepare employees for a new way of functioning and working in a crisis situation in order to ensure business continuity with as few negative consequences for stakeholders as possible.

Existing knowledge has shown that the spread of COVID-19 can be prevented/slowed down by increasing the physical distance between people and improving their hygiene habits (Dutch 
Leonard, Howitt, \& Giles, 2020). Therefore, employers had to reconsider their processes and ways of working, as well as implement certain organizational changes in order to protect and preserve the health and safety of their employees (Pastakia, Kearsey, Kilpatrick, \& Moir, 2020).

During the COVID-19 pandemic, a number of HR policies and practices underwent significant changes. In most countries, government decided that people should work from home as much as possible (Stoker, Garretsen \& Lammers, 2021). The implications of this crisis were mostly related to the following HR activities (Vnoučková, 2020):

- (Re)organizing, (re)structuring, and creating conditions for remote work (redesigning jobs, work tasks, job descriptions, and adapting to newly changed working circumstances providing conditions for working from home, controlling the execution of tasks, organizing employees into work teams.

- Providing conditions for the protection of health and safety of employees (application of measures for the use of protective equipment - masks gloves, disinfectants, etc.).

- Managing all levels of remote management and coordinating different teams' work.

- Activities by the crisis management whose focus is to create an efficient crisis management team that will adapt to the new circumstances on a daily basis.

- Organizing and implementing employees' online training in the use of modern technology, software, systems, digital tools, video conferencing, etc. with the aim of ensuring the most efficient communication and fast and secure exchange of information between employees.

- Dealing with a possible high degree of employee turnover, changed structure of employees, reduction of salaries, dismissals, etc.

- Managing stress caused by fear of change, illness, job loss, etc. and the need for the HR department to show support and greater understanding and empathy for employees.

In practice, organizations have reorganized their functioning and introduced working from home, flexible working hours, shift work, physical distancing in the workplace, enhanced hygiene and disinfection of the workplace (European Centre for Disease Prevention and Control, 2020; Reeves, Faeste, Chen, Carlsson-Szlezak, \& Whitaker, 2020). Many organizations have made additional efforts to transparently present all the consequences that may result from the irresponsible behaviour of employees in case they experience cold symptoms, fever, or respiratory problems that may indicate the existence of COVID-19. The results of a survey conducted in companies in China on a sample of 1000 respondents showed that over $90 \%$ of employers introduced working from home (wherever possible), flexible working hours, physical distancing, and enhanced hygiene measures (Pastakia et al., 2020). A research in Australia also confirmed the fact that the role of human resource professionals, as well as their professionalism and expertise, has grown significantly in those organizations that sought to be agile and effectively adaptable to the health crisis, and which showed a high level of trust and additional care for its employees (Aitken-Fox et al., 2020). All these activities foster organizational commitment of employees and have significant impact on the overall organizational functioning and performance (Đorđević, Ivanović-Đukić, Lepojević, \& Milanović, 2020).

\section{Research methodology}

An empirical study, using a specially designed questionnaire, was conducted in the paper. One of the aims of the questionnaire was to examine the activities carried out by the HR department in organizations during the crisis caused by the COVID-19 pandemic.

The questionnaire consisted of several groups of questions: (1) questions related to the respondents (gender, length of service in the organization, position in the organization); (2) issues related to the organization in which respondents work (sector, activity, number of employees); (3) statements in the form of a fivepoint Likert scale related to the role and activities of the HR department in the crisis situation caused by the COVID-19 pandemic. This Likert scale is called The role of $H R$ department in crisis situations.

The questionnaire was carried out electronically and placed by sending a direct link to the questionnaire to companies, HR associations, as well as professional (LinkedIn, ResearchGate) and social networks (Facebook groups of HR experts and managers). During 
2020, a total of 108 respondents answered the questionnaire. The collected responses were processed by using the Statistical Package for Social Sciences - SPSS, version 21.0. (Armonk, NY: IBM Corporation).

The Cronbach's Alpha coefficient for all statements in the Likert scale The role of the HR department in crisis situations was 0.954 which demonstrated a high degree of reliability of the scale.

Kolmogorov-Smirnov test, as well as histograms, skewness, kurtosis, normal probability curve (Q-Q plot) and boxplot showed the normality of data distribution.

\section{Key sample information}

The largest number of respondents (44\%) come from medium-sized organizations (with 50 to 249 employees), but there are $29 \%$ respondents who work in organizations that are small (up to 49 employees) and $27 \%$ of respondents who work in large organizations (over 250 employees).

The largest number of respondents work in private sector organizations $(63 \%)$, while $37 \%$ of respondents work in public sector organizations. Respondents who participated in the survey come from three countries: Serbia $(56.5 \%)$, Bosnia and Herzegovina (30.5\%), and Croatia (13\%).

In terms of the activities of organizations, the largest number of respondents are from the education (37\%), manufacturing (15\%), and health sectors $(14 \%)$. About one third of respondents belong to the sectors: banking and finance $(8.3 \%)$, trade $(7.4 \%)$, consulting services (7.4\%), government agencies $(6.5 \%)$, and transport and logistics $(4.6 \%)$.
Male and female respondents are almost equally represented in the sample $(51 \%$ of men and $49 \%$ of women). More than half of the respondents $(54 \%)$ have over 10 years of work experience in a given organization, while $22 \%$ have 6 to 10 years, and $21 \%$ have 1 to 5 years of work experience.

In terms of position, the majority of respondents are in top management positions (34\%) and middle management positions (33\%). About $16 \%$ of respondents are first-line managers, while $17 \%$ of respondents do not hold managerial positions.

\section{Research results and discussion}

A Likert scale called The role of the $H R$ department in crisis situations, consisting of eight statements aimed at identifying activities undertaken by the HR department due to the COVID-19 pandemic, was formed for the purposes of this research. Respondents were asked to mark each of the eight statements with a number from 1 to 5 , depending on the degree to which they agreed with the statements (1 indicated that respondents completely disagree, while 5 indicated that respondents fully agree).

Table 1 shows the mean score of respondents for the statements from the scale The role of the $H R$ department in crisis situations. The first four statements (numbers 1 to 4 in Table 1) refer to the reorganization and redesign of jobs and ways of working. The three statements in the Likert scale (numbers 5 to 7 in Table 1) refer to the activities of preserving the health and safety of employees during the COVID-19 pandemic. One of the statements in the Likert scale was dedicated to stress management during the COVID-19 pandemic (ordinal number 8 in the table 1).

Table 1 Mean score for the statements in the scale "The role of the HR department in crisis situations"

\begin{tabular}{c|l|c}
\hline No. & \multicolumn{1}{|c}{ Statements } & Mean score \\
\hline 1 & $\begin{array}{l}\text { When the crisis event happened, the HR department immediately undertook activities of planning and } \\
\text { reorganizing employees. }\end{array}$ & 3.82 \\
\hline 2 & The HR department redesigned the workplace (physical distance between office desks) & 3.70 \\
\hline 3 & The HR department introduced flexible working hours. & 4.25 \\
\hline 4 & The HR department introduced working from home where possible. & 4.33 \\
\hline 5 & The HR department immediately took measures to improve workplace hygiene. & 4.18 \\
\hline 6 & The HR department provided disinfectants (soap, antiseptic, etc.). & 4.27 \\
\hline 7 & $\begin{array}{l}\text { Since the crisis, the HR department has promoted a policy that employees who have symptoms of } \\
\text { COVID-19 (fever, dry cough, fatigue, aches and pains, sore throat, diarrhoea, conjunctivitis, loss of } \\
\text { taste or smell, a rash on skin) should stay at home. }\end{array}$ & 4.40 \\
\hline 8 & $\begin{array}{l}\text { During the crisis, the HR department helped employees to overcome the problem of adapting to } \\
\text { changed working conditions. }\end{array}$ & 4.18 \\
\hline
\end{tabular}


Mean scores for all statements within the scale The role of the HR department in crisis situations are above 3.7, which is a positive result (all scores above the limit value of 3 are positive). Rapid (instant) reaction to emerging crisis events greatly contributes to the process of stabilization of the organization and its way of functioning. Also, an adequate response from the HR department leads to the creation of an agile, sustainable, and resilient organization that is able to change its way of functioning, to be flexible, and to adapt and survive regardless of the circumstances (Paauwe \& Boon, 2019).

\subsection{Reorganization and redesign of jobs: research results and discussion}

One of the first issues that organizations faced was how to make a seating plan so as to provide a safe physical distance between employees (Caminiti, 2020). The results showed that $62 \%$ of respondents agree with the statement that, as soon as crisis began, the HR department undertook planning and reorganization activities.

Almost two-thirds of the respondents (61.1\%) agree with the statement that the HR department has redesigned the workplace (physical distance between office desks) in order to preserve the health and safety of employees. In situations where this was possible, flexible working hours and the possibility of working from home were introduced. Of the total number of respondents, $75 \%$ agree with the statement that the HR department has introduced flexible working hours and $75.9 \%$ that the HR department has introduced working from home. These results are not surprising because, even before the COVID-19, work from home and virtual project teams were on the rise.

Responsibilities and duties of employees that work from home are the same as for the employees that are physically present at the office, but there are some challenges that should be overcome (Lukić \& Vračar, 2018). It is necessary to provide appropriate guidelines, instructions and advice to employees on how to quickly adjust to circumstances that many of them encounter for the first time. The HR department should maintain a pleasant working atmosphere and provide employees with all the necessary information in real time regarding the current situation with COVID-19, prevention measures, hygiene measures, working conditions.

\subsection{Employee health and safety: research results and discussion}

Employee health and safety are key priorities for organizations because employees have become the most important source of competitive advantage (Reilly, 2008; Lazarević, 2014).

The results showed that $71.3 \%$ of the total number of respondents agree with the statement that the HR department immediately took measures to improve the hygiene of the workplace, while $74.1 \%$ of respondents agree with the statement that the HR department provided disinfectants (soap, antiseptic, etc.).

A very important practice implemented by the HR department is to promote the stay-at-home policy if employees experience any of the symptoms of the virus (fever, dry cough, fatigue, aches and pains, sore throat, diarrhoea, conjunctivitis, loss of taste or smell, a rash on skin) - the results showed that $77.8 \%$ of respondents agreed with this statement. No organization wants its employees coming to work sick, especially in the conditions of the COVID19 pandemic.

Organizations that truly care about the health and safety of their employees have a significantly higher chance of long-term success compared to organizations that only care about processes, infrastructure, and legal regulation (Athamneh, 2018). The unpredictable spread of COVID-19 means that circumstances and instructions are changing on a daily basis and HR departments need to provide an adequate answer to them. Through history, modern information and communication technologies transferred businesses beyond the formal boundaries of the organization and consequently raised the importance of organizational trust (Petković \& Lukić, 2013). During COVID-19 pandemic, employees more than ever need to trust each other and their managers and to behave responsibly regarding safety measures and changed working conditions.

\subsection{Stress management: research results and discussion}

Stress management is a very important activity for the normal functioning of both employees and organizations, especially in crisis situations (Reilly, 2008). Every crisis is an emotional event that affects employees (Kaplan, LaPort, \& Waller, 2013). World Health Organization stated that COVID-19 pandemic is affecting the mental health of many people around the world because 
of the new ways of working and fear of global recession and uncertainty (World Health Organization, 2020). Namely, employees faced new methods and ways of working such as: working from home (where they often do not have ideal conditions - workspace, work atmosphere), intensive communication via e-mail and other online tools, a constant inflow of new information, constant availability of employees during a state of emergency (when managers knew that employees are at home near computers and telephones), changed level of autonomy, changed perception of hierarchies and sense of remoteness (Delfino \& van der Kolk, 2021). Some employees even felt a sense of loss because they replaced frequent business travels, meetings, and dinners with isolation, quarantine, and virtual meetings (Caligiuri, De Cieri, Minbaeva, Verbeke, \& Zimmermann, 2020). These changed working conditions have been a significant source of stress for many employees. In addition, job insecurity and the fulfilment of set goals, which in recent years have been positioned as a significant stressor for employees, have become even greater during the crisis situation. Workload pressure, task interdependence, concerns about underpayment and/or delayed payment, and family obligations lead to additional stress (Jamal, Anwar, Khan, \& Saleem, 2021; Oruh, Mordi, Dibia, \& Ajonbadi, 2021).

The way in which employees interpret all those stressors determines their response to stress. Stress leads to numerous negative effects that are not only reflected on the employees' health and work results, but also on the results and the way of functioning of the entire organization (Lukić \& Lazarević, 2019). For this reason, it is very important for HR departments to apply a holistic approach to stress management and to provide assistance and support to employees facing stressful situations (Lukić \& Lazarević, 2018). Stress management programs for employees that will help them cope with stress, loneliness that is a result of social and physical distancing, and anxiety are especially important in crisis situations (Caminiti, 2020).

The results of the survey showed that $74.1 \%$ of respondents agree with the statement that the HR department helped employees to adapt as easily and quickly as possible to new, changed circumstances and ways of working during the crisis situation. A significant activity carried out by the organizations is the training and education of employees on how to fit into the new way of working and working conditions, both physically (adjusting the infrastructure and working environment for working from home) and mentally (how to deal with uncertainty, stress, anxiety, and fear). This activity was very helpful because every time employees face new pressures they need suitable skills, knowledge and abilities (Slavić \& Berber, 2019).

\section{Implications, contributions and limitations of research}

The conducted research has several significant implications and contributions. First, the results of the research showed that the HR department takes a leading role in crisis situations. From the sector that was considered to have a key role in recruitment, payroll, and dismissal, the HR department has gradually gained a strategic role in organizations, which is especially evident in crisis situations (Grant, 2016; Naznin \& Hussain, 2016). It is certain that the role of the HR department in the future will evolve further towards exploiting all the potentials of employees and achieving organizational goals (Foot, Hook, \& Jenkins, 2016). Second, the research showed that the HR department has several different methods and ways that can enable employees to work in a quality and efficient manner, with maximum safety and health preservation. Many activities, practices, and principles implemented by the HR department during the crisis situation caused by COVID-19 have further strengthened long-term trends such as the flexibility of working hours, opportunities to work from home, compression of the working week. These trends have been largely prompted by the fourth industrial revolution, that is, thanks to the use of modern information and communication technologies and tools. Employees who worked from home and had flexible working hours during COVID-19 pandemic gained valuable experience and perceived what the future of work could look like. Third, the paper presents examples of wellimplemented HR practices, so organizations can acquire adequate knowledge through the learning process and be better prepared for future crisis situations. Crises caused by threats to public health have existed in the past (e.g. SARS) and it is certain that they will occur in the future. Therefore, the acquired knowledge and experience can be very beneficial for crisis management and employee care.

The conducted research is accompanied by certain limitations. First of all, the research was 
conducted in three countries: Serbia, Bosnia and Herzegovina, and Croatia and included a total of 108 respondents, which is why it is not justified to generalize the obtained conclusions. The research should be extended to other countries and include a larger number of respondents. In future research into this topic, it would be valuable to include issues related to the work-life balance, because working from home and modern technology can often blur the boundaries between these two opposing worlds.

The results of this paper indicate that this health crisis in the field of work practice and human resource management will provide guidelines that can be generally accepted by the top management and HR department, which can be a good basis for applying the new working norm in such and similar crisis situations.

HR department in organizations will be a key lever in achieving organizational agility. Agile organizations are able to predict, perceive and quickly respond to unexpected situations in productive, creative, efficient and effective way that creates new added value (Balog, 2020).

\section{Conclusion}

The HR department is highly responsible for the functioning and operating of any organization. Many organizations have become aware that employees are the most significant and valuable capital and have begun to direct their efforts towards creating a better and more positive employee experience. If there are problems in the functioning and operating of the HR department, the organization is in danger because it is exposed to many problems and difficulties.

Weaknesses in the functioning of the HR department are especially pronounced in crisis situations that have become inevitable in the life cycle of any organization. One of the crises that affected the whole world at the beginning of 2020 is the COVID-19 pandemic, which poses a threat to human health.

The results of a survey conducted in Serbia, Bosnia and Herzegovina, and Croatia during 2020 on a sample of 108 respondents, have shown that the HR department in organizations responded quickly to the crisis caused by the COVID-19 pandemic. Most employees could work from home (when the nature of the job allowed it), flexible working hours, the process of reorganization of the working space was carried out in order to satisfy the need to maintain physical distance between employees, disinfectants were provided, and workplace hygiene measures were enhanced. In addition, the research results showed that, during the global COVID-19 pandemic, the HR departments took an active role in providing psychological assistance to employees to adapt to new conditions and ways of working. Apart from all activities undertaken by HR department, employees' cooperation and adaptability are needed to ensure working processes run smoothly.

On the other hand, employees who are aware that the organization truly cares about them, that it has done everything it could to protect and preserve their health, safety, job security during crisis, show a greater degree of loyalty, commitment, and engagement.

Organizations that have a strong HR department and loyal, committed and engaged employees are fearless organizations that can cope with any type of crisis and win.sm

\section{References}

Aitken-Fox, E., Coffey, J., Dayaram, K., Fitzgerald, S., Gupta, C., McKenna, S., \& Tian, A.W. (2020). The impact of Covid-19 on human resource management: avoiding generalisations. Retrieved May 15, 2021, from https://blogs.Ise.ac.uk/businessreview/2020/05/22/theimpact-of-covid-19-on-human-resource-managementavoiding-generalisations/

Athamneh, S. (2018). HR Planning for crisis management. IntechOpen. https://doi.org/10.5772/intechopen.75233

Balog, K. (2020). The concept and competitiveness of agile organization in the fourth industrial revolution's drift. Strategic Management, 25(3), 14-27. https://doi.org/10.5937/StraMan2003014B

Barton, L. (2000). Crisis in organizations. Cincinnati, Ohio: South-Western College Publishing.

Burma, Z. A. (2014). Human resource management and its importance for today's organizations. International Journal of Education and Social Science, 1(2), 85-94.

Caligiuri, P., De Cieri, H., Minbaeva, D., Verbeke, A., \& Zimmermann, A. (2020). International HRM insights for navigating the COVID-19 pandemic: Implications for future research and practice. Journal of International Business Studies, 51, 697-713. https://doi.org/10.1057/s41267-020-00335-9

Caminiti, S. (2020). How the coronavirus crisis has elevated the role of HR chiefs in the C-suite. Retrieved April 20, 2021, from https://www.cnbc.com/2020/04/22/thecoronavirus-is-elevating-the-role-of-hr-chiefs-in-the-csuite.html

Carnevale, J. B., \& Hatak, I. (2020). Employee adjustment and well-being in the era of COVID-19: Implications for human resource management. Journal of Business Research, 116, 183-187. https://doi.org/10.1016/j.jbusres.2020.05.037

Delfino, G.F., \& van der Kolk, B. (2021). Remote working, management control changes and employee responses during the COVID-19 crisis. Accounting, Auditing \& Accountability Journal, 34(6), 1376- 1387. https://doi.org/10.1108/AAAJ-06-2020-4657 
Dutch Leonard, H., Howitt, A., \& Giles, D. (2020). Twenty things for organizational leaders to know about Covid19. Retrieved April 15, 2021, from https://www.hks.harvard.edu/sites/default/files/centers/r esearchinitiatives/crisisleadership/files/Twenty Things for Lea ders to Know about Covid 19 PCLweb.pdf

Đorđević, B., Ivanović-Đukić, M., Lepojević, V., \& Milanović, S. (2020). The impact of employees' commitment on organizational performances. Strategic Management, 25(3), 28-37. https://doi: 10.5937/StraMan2003028D

European Centre for Disease Prevention and Control (2020). Novel coronavirus disease 2019 (COVID-19) pandemic: Increased transmission in the EU/EEA and the UK - sixth update - 12 March 2020. Stockholm: ECDC.

Federman, B. (2009). Employee Engagement A Roadmap for Creating Profits, Optimizing Performance, and Increasing Loyalty. San Francisco: Jossey-Bass.

Figus, A. (2021). Social evolution in times of COVID-19 between politics, economics, and health. Strategic Management, 26(1), 66-72. https://doi.org/10.5937/StraMan2101066F

Foot, M., Hook, C., \& Jenkins, A. (2016). Introducing Human Resource Management. Harlow: Pearson Education limited.

Grant, R. M. (2016). Contemporary Strategy Analysis: Text and Cases. New York: Wiley \& Sons.

Gunnigle, P., Lavelle, J., \& Monaghan, S. (2019). Multinational companies and human resource management in Ireland during recession: A retrospective from a highly globalized economy. Thunderbird International Business Review, 61(3), 481 489. https://doi.org/10.1002/tie.21978

Hart, P., Rosenthal, U., \& Kouzmin, A. (1993). Crisis decision making: The centralization thesis revisited. Administration \& Society, 25(1), 12-44. https://doi.org/10.1177/009539979302500102

Human Resources Management Association (2014). The Roles of Human Resources in Organizational Crisis Management. Vancouver: HRMA.

Jamal, M. T., Anwar, I., Khan, N. A., \& Saleem, I. (2021). Work during COVID-19: Assessing the influence of job demands and resources on practical and psychological outcomes for employees. Asia-Pacific Journal of Business Administration, 13(3), 293-319. https://doi.org/10.1108/APJBA-05-2020-0149

Jaganjac, J., \& Obhođaš, I. (2019). The impact of demographic trends in the Federation of Bosnia and Herzegovina on higher education, labour market efficiency and innovation. Časopis za ekonomiju $i$ tržišne komunikacije, 17(1), 171-184. http://dx.doi.org/10.7251/EMC19011710

Kaplan , S., LaPort, K., \& Waller, M. J. (2013). the role of positive affectivity in team effectiveness during crises. Journal of Organizational Behavior, 34, 473-491. https://doi.org/10.1002/job.1817

Lazarević, S. (2014). Timsko učenje u funkciji razvoja birokratizovane organizacije kao organizacije koja uči. Teme, 2, 837-853.

Lukić, J., \& Lazarević, S. (2018). Sources of workplace stress in service sector organizations. Facta Universitatis, Series: Economics and Organization, 15(3), 217-229. https://doi.org/10.22190/FUEO1803217L
Lukić, J., Vračar, M. (2018). Building and nurturing trust among members in virtual project teams. Strategic Management, 23(3), 10-16. https://doi.org/10.5937/StraMan1803010L

Lukić, J., \& Lazarević, S. (2019). A holistic approach to workplace stress management. School of Business, 1 , 130-144. https://doi.org/10.5937/skolbiz1-21872

Lukić, J., Jaganjac, J., \& Lazarević, S. (2020). The successfulness of crisis management teams' response to crisis caused by COVID-19 pandemic. Ekonomika preduzeća, 68(7-8), 545-556. https://doi.org/10.5937/EKOPRE2008545L

Lukić Nikolić, J. (2021). Angažovanost zaposlenih sa organizacionim ponašanjem i menadžmentom ljudskih resursa. Beograd: Visoka škola modernog biznisa.

Meister, J. (2020). The impact of the coronavirus on HR and the new normal of work. Retrieved May 10, 2021, from https://www.forbes.com/sites/jeannemeister/2020/03/31 the-impact-of-the-coronavirus-on-hr-and-the-newnormal-of-work/\#4349c3142b60

Mirzapour, M., Toutian, S. S., Mehrara, A., \& Khorrampour, S. (2019). The strategic role of human resource management in crisis management considering the mediating role of organizational culture. International Journal of Human Capital in Urban Management, 4(1), 43-50

Mitroff, I. I. (1988). Crisis management: Cutting through the confusion. Sloan Management Review, 29(2), 15-20.

Mwaniki, R., \& Gathenya, J. (2015). role of human resource management functions on organizational performance with reference to Kenya Power \& Lighting Company Nairobi West Region. International Journal of Academic Research in Business and Social Sciences, 5(4), 432448. https://doi.org/10.6007/IJARBSS/v5-i4/1584

Naznin, H., \& Hussain, M. (2016). Strategic value contribution role of HR. Vision, 20(2), 135-138. https://doi.org/10.1177/0972262916637274

Oruh, E. S., Mordi, C., Dibia, C. H., \& Ajonbadi, H. A. (2021). Exploring compassionate managerial leadership style in reducing employee stress level during COVID19 crisis: The case of Nigeria. Employee Relations, 43(6), 1362-1381.

https://doi.org/10.1108/ER-06-2020-0302

Paauwe, J., \& Boon, C. (2018). Strategic HRM: A critical review. In D. G. Collings, G. T. Wood \& L. T. Szamosi (Eds.), Human Resource Management - A Critical Approach (pp. 49-73). London and New York: Routledge, Taylor \& Francis Group. https://doi.org/10.4324/9781315299556-3

Pastakia, K., Kearsey, J., Kilpatrick, J., \& Moir, J. (2020). Covid-19: Practical workforce strategies that put your people first, Deloitte. Retrieved May 5, 2021, from https://www2.deloitte.com/content/dam/Deloitte/global/D ocuments/About-Deloitte/gx-workforce-strategies-thatput-your-people-first.pdf

Petković, M., \& Lukić, J. (2013). The impact of information technology on organizational desing: Example in health organization. Sociologija, 55(3), 439-460. https://doi.org/10.2298/SOC1303439P

Reeves, M., Faeste, L., Chen, C., Carlsson-Szlezak, P., \& Whitaker, K. (2020). How Chinese companies have responded to coronavirus. Retrieved April 29, 2021, from https://hbr.org/2020/03/how-chinese-companieshave-responded-to-coronavirus 
Reilly, A. H. (2008). The role of human resource development competencies in facilitating effective crisis communication. Advances in Developing Human Resources, 10(3), 331-351. https://doi.org/10.1177/1523422307313659

Slavić, A., \& Berber, N. (2019). The Role of Training Practice in Improving Organizational Performance in Selected Countries of the Danube Region. Inzinerine Ekonomika-Engineering Economics, 30(1), 81-93. https://doi.org/10.5755/j01.ee.30.1.17857

Sparrow, P., Hird, M., \& Cooper, C. L. (2015). Do We Need HR? Repositioning People Management for Success. New York: Palgrave MacMillan. https://doi.org/10.1057/9781137313775

Stoker, J. I., Garretsen, H., \& Lammers, J. (2021). Leading and working from home in times of COVID-19: on the perceived changes in leadership behaviors. Journal of Leadership \& Organizational Studies, 1-11. https://doi.org/10.1177/15480518211007452

Tansey, C. (2020). How HR should handle Coronavirus concerns. Retrieved May 5, 2021, from https://www.zenefits.com/workest/how-hr-shouldhandle-coronavirus-concerns/

Vnoučková, L. (2020). Impact of COVID-19 on human resource management. Revista Latinoamericana De Investigación Social, 3(1), 18-21.

\section{$\triangle$ Correspondence}

\section{Jelena Lukić Nikolić}

High School of Modern Business Terazije 27/4, 11000 Belgrade, Serbia

E-mail: jelena.lukic@mbs.edu.rs
Wang, J. (2008). Developing organizational learning capacity in crisis management. Advances in Developing Human Resources, 10(3), 425-445. https://doi.org/10.1177/1523422308316464

Wooten, L. P., \& James, E. H. (2008). Linking crisis management and leadership competencies: The role of human resource development. Advances In Developing Human Resources, 20(10), 1-28. https://doi.org/10.1177/1523422308316450

World Health Organization (2020). Physical and mental health key to resilience during COVID-19 pandemic. Retrieved May 3, 2021, from http://www.euro.who.int/en/health-topics/healthemergencies/coronavirus-covid19/statements/statement-physical-and-mental-healthkey-to-resilience-during-covid-19-pandemic

Yang, Y., Peng, F., Wang, R., Guan, K., Jiang, T., Xu, G., Sun, J., \& Ghang, C. (2020). The deadly coronaviruses: The 2003 SARS pandemic and the 2020 novel coronavirus epidemic in China. Journal of Autnoimmunity. https://doi.org/10.1016/j.jaut.2020.102487 